\title{
Role of echocardiography and phonocardiography in diagnosis of mitral paraprosthetic regurgitation with Starr-Edwards prostheses
}

\author{
H. C. Miller ${ }^{1}$, D. G. Gibson, and J. D. Stephens \\ From the Cardiac Department, Brompton Hospital, Fulham Road, London
}

Twenty-three patients who were symptomatic after mitral valve replacement, and in whom mitral paraprosthetic regurgitation was a possible cause of deterioration, were investigated by cardiac catheterization, phonocardiography, and echocardiography. Severe paraprosthetic regurgitation was present in II patients and slight regurgitation in 2 patients. Two patients had aortic regurgitation which was responsible for their symptoms and the remaining 9 patients had either poor left ventricular function, an obstructed mitral prosthesis, or an obstructed tricuspid prosthesis. The various groups could not be identified on clinical, radiological, or electrocardiographic features, but severe paraprosthetic regurgitation was associated with a reduced $A_{2}-O C$ interval on phonocardiography and normal septal movement with a large stroke volume on echocardiography. In view of the difficulties in clinical diagnosis, the value of phonocardiography and echocardiography has been emphasized, particularly in ill patients in whom, on the basis of these investigations, cardiac catheterization may be avoided.

The results of mitral valve replacement continue to improve (Barclay et al., 1972; Morrow et al., 1967; Najafi et al., 1969; Starr, 1971). In a small proportion of patients, however, the outcome may be disappointing and though this is usually due to irreversible left ventricular disease, the possibility of malfunction of the prosthesis or of additional uncorrected valve disease must always be considered (Peterson et al., 1967; Rockoff et al., 1966). Unfortunately, clinical diagnosis in this situation is unreliable, so that a number of attempts have been made to use non-invasive techniques in order to improve diagnostic accuracy (Willerson et al., 1972; Wise, Webb-Peploe, and Oakley, 197I). We have studied a group of patients who deteriorated after mitral valve replacement with a Starr-Edwards prosthesis, correlating the clinical, phono-, and echocardiographic features with the results of investigation by cardiac catheterization and angiography in order to define their role in the diagnosis of mitral paraprosthetic leak.

\section{Subjects}

Twenty-four patients were studied. All had mitral valve replacement with a Starr-Edwards prosthesis, and all

Received 25 June 1973.

${ }^{2}$ Present address: Department of Medicine, Duke University Medical Center, Durham, North Carolina, U.S.A. were investigated on account of deteriorating exercise tolerance or the development of clinical evidence of heart failure, with mitral paraprosthetic regurgitation as an important diagnostic possibility. They were divided into 4 groups on the basis of the final diagnosis made after cardiac catheterization (23 patients) or reoperation. Pertinent clinical details are given in Table I.

Group I consisted of 9 patients in whom there was no evidence of paraprosthetic leak demonstrable by left ventriculography. Symptoms were eventually ascribed to an obstructed mitral prosthesis in I, to an obstructed tricuspid prosthesis in a second, and to left ventricular disease in the remainder, one of whom had in addition a small fistula between the left ventricle and coronary sinus.

Group 2 consisted of 2 patients in whom symptoms were ascribed to left ventricular disease, but who had, in addition, small leaks associated with the prosthesis. Operation was not advised in either and they continue on medical treatment.

Group 3 consisted of II patients with severe mitral paraprosthetic leak, which was felt to be the cause of symptoms and who were therefore referred for operation.

Group 4 contained 2 patients in whom symptoms were due primarily to aortic regurgitation, not corrected at the time of the first operation. Both were considerably improved after aortic valve replacement.

\section{Cardiac catheterization and angiography}

This was performed using standard techniques. Left ventriculography was performed in the right anterior 
TABLE I Clinical features

\begin{tabular}{|c|c|c|c|c|c|c|c|c|}
\hline $\begin{array}{l}\text { Case } \\
\text { No. }\end{array}$ & $\begin{array}{l}\text { Age } \\
\text { and } \\
\text { sex }\end{array}$ & $\begin{array}{l}\text { Onset of } \\
\text { deteriora- } \\
\text { tion after } \\
\text { operation }\end{array}$ & $\begin{array}{l}\text { Previous operation } \\
\text { on mitral valve }\end{array}$ & $\begin{array}{l}\text { Factors } \\
\text { predisposing to } \\
\text { mitral para- } \\
\text { prosthetic } \\
\text { regurgitation }\end{array}$ & $\begin{array}{l}\text { Tricuspid } \\
\text { regurgn }\end{array}$ & $\begin{array}{l}\text { Systolic } \\
\text { murmur }\end{array}$ & Haemolysis & Remarks \\
\hline \multicolumn{9}{|c|}{ Group I } \\
\hline I & $65 \mathrm{~F}$ & $8 \mathrm{mth}$ & Nil & Ruptured chordae & Present & Soft apical & Nil & LV failure \\
\hline 2 & $44 \mathrm{~F}$ & I5 & $\begin{array}{l}\text { Closed mitral } \\
\text { valvotomy (2) }\end{array}$ & None & & None & + & $\begin{array}{l}\text { Obstructed mitral } \\
\text { prosthesis }\end{array}$ \\
\hline 3 & $5 \mathrm{IF}$ & 9 " & Nil & Floppy valve & Present & Soft apical & NR & LV failure \\
\hline 4 & $5 \mathrm{IF}$ & 3 & Nil & None & Present & Soft apical & Nil & LV failure \\
\hline 5 & $4 \mathrm{IF}$ & $7 \frac{1}{2} \mathrm{yr}$ & Nil & None & - & None & Nil & $\begin{array}{l}\text { Also tricuspid } \\
\text { valve replace- } \\
\text { ment, partially } \\
\text { obstructed }\end{array}$ \\
\hline 6 & $54 \mathrm{~F}$ & $15 \mathrm{mth}$ & Nil & None & Present & $\begin{array}{l}\text { Soft apical } \\
+ \text { left } \\
\text { sternal edge }\end{array}$ & NR & LV failure \\
\hline 7 & $60 \mathrm{~F}$ & II , & $\begin{array}{l}\text { Closed mitral } \\
\text { valvotomy }\end{array}$ & Calcification + & Present & $\begin{array}{l}\text { Soft left } \\
\text { sternal edge }\end{array}$ & NR & LV failure \\
\hline 8 & $46 M$ & $4 \frac{1}{2} \mathrm{yr}$ & $\begin{array}{l}\text { Closed mitral } \\
\text { valvotomy (2) }\end{array}$ & Calcification ++ & Present & $\begin{array}{l}\text { Soft left } \\
\text { sternal edge }\end{array}$ & NR & LV failure \\
\hline 9 & $58 \mathrm{~F}$ & $2 \mathrm{mth}$ & $\begin{array}{l}\text { Closed mitral } \\
\text { valvotomy }\end{array}$ & Calcification ++ & Present & Soft apical & NR & $\begin{array}{l}\text { LV failure: also } \\
\text { LV to coronary } \\
\text { sinus fistula }\end{array}$ \\
\hline \multicolumn{9}{|c|}{ Group 2} \\
\hline 10 & $56 \mathrm{~F}$ & $39 \mathrm{mth}$ & $\begin{array}{l}\text { Closed mitral } \\
\text { valvotomy (3) }\end{array}$ & None & Present & $\begin{array}{l}\text { Soft apical } \\
\text { + left sternal } \\
\text { edge, aortic } \\
\text { systolic } \\
\text { murmur }\end{array}$ & Nil & $\begin{array}{l}\text { Slight mitral } \\
\text { paraprosthetic } \\
\text { regurgn }+ \\
\text { LV failure }\end{array}$ \\
\hline II & $64 M$ & $5 \mathrm{yr}$ & Nil & Calcification ++ & Present & Soft apical & Nil & $\begin{array}{l}\text { Slight mitral } \\
\text { paraprosthetic } \\
\text { regurgn + } \\
\text { LV failure }\end{array}$ \\
\hline \multicolumn{9}{|c|}{ Group 3} \\
\hline 12 & $56 \mathrm{~F}$ & $20 \mathrm{mth}$ & $\begin{array}{l}\text { Closed mitral } \\
\text { valvotomy; } \\
\text { homograft } \\
\text { mitral valve } \\
\text { replacement }\end{array}$ & Calcification + & Present & $\begin{array}{l}\text { Soft apical }+ \\
\text { left sternal } \\
\text { edge; aortic } \\
\text { systolic } \\
\text { murmur }\end{array}$ & ++ & $\begin{array}{l}\text { Mitral parapros- } \\
\text { thetic regurgita- } \\
\text { tion, also } \\
\text { aortic valve } \\
\text { replacement }\end{array}$ \\
\hline 13 & $40 F$ & 6 , & $\begin{array}{l}\text { Homograft } \\
\text { mitral valve } \\
\text { replacement }\end{array}$ & Calcification + & Present & $\begin{array}{l}\text { Soft left } \\
\text { sternal edge }\end{array}$ & + & $\begin{array}{l}\text { Mitral para- } \\
\text { prosthetic } \\
\text { regurgitation }\end{array}$ \\
\hline 14 & $58 \mathrm{~F}$ & 3 & $\begin{array}{l}\text { Closed mitral } \\
\text { valvotomy; } \\
\text { homograft } \\
\text { mitral valve } \\
\text { replacement }\end{array}$ & Calcification ++ & Present & Soft apical & + & $\begin{array}{l}\text { Mitral para- } \\
\text { prosthetic } \\
\text { regurgitation, } \\
\text { also aortic valve } \\
\text { replacement }\end{array}$ \\
\hline 15 & $47 \mathrm{~F}$ & I & $\begin{array}{l}\text { Homograft mitral } \\
\text { valve replace- } \\
\text { ment }\end{array}$ & Nil & Present & $\begin{array}{l}\text { Soft apical }+ \\
\text { left sternal } \\
\text { edge }\end{array}$ & Nil & $\begin{array}{l}\text { Mitral para- } \\
\text { prosthetic } \\
\text { regurgitation }\end{array}$ \\
\hline 16 & $48 \mathrm{M}$ & $51 \%$ & $\begin{array}{l}\text { Mitral para- } \\
\text { prosthetic } \\
\text { regurgitation } \\
\text { (reattd) }\end{array}$ & Calcification ++ & Present & $\begin{array}{l}\text { Soft apical }+ \\
\text { left sternal } \\
\text { edge }\end{array}$ & ++ & $\begin{array}{l}\text { Mitral para- } \\
\text { prosthetic } \\
\text { regurgitation }\end{array}$ \\
\hline 17 & $59 \mathrm{~F}$ & $13 \%$ & $\begin{array}{l}\text { Closed mitral } \\
\text { valvotomy; } \\
\text { homograft } \\
\text { mitral valve } \\
\text { replacement }\end{array}$ & Calcification + & - & $\begin{array}{l}\text { Intermittent } \\
\text { apical }\end{array}$ & Nil & $\begin{array}{l}\text { Mitral para- } \\
\text { prosthetic } \\
\text { regurgitation } \\
\text { on angiogram; } \\
\text { not seen at } \\
\text { re-op.; further } \\
\text { mitral valve } \\
\text { replacement; } \\
\text { patient well }\end{array}$ \\
\hline
\end{tabular}




\begin{tabular}{|c|c|c|c|c|c|c|c|c|}
\hline $\begin{array}{l}\text { Case } \\
\text { No. }\end{array}$ & $\begin{array}{l}\text { Age } \\
\text { and } \\
\text { sex }\end{array}$ & $\begin{array}{l}\text { Onset of } \\
\text { deteriora- } \\
\text { tion after } \\
\text { operation }\end{array}$ & $\begin{array}{l}\text { Previous operation } \\
\text { on mitral valve }\end{array}$ & $\begin{array}{l}\text { Factors } \\
\text { predisposing to } \\
\text { mitral para- } \\
\text { prosthetic } \\
\text { regurgitation } \\
\end{array}$ & $\begin{array}{l}\text { Tricuspid } \\
\text { regurgn }\end{array}$ & $\begin{array}{l}\text { Systolic } \\
\text { murmur }\end{array}$ & Haemolysis & Remarks \\
\hline 18 & $56 \mathrm{M}$ & 2 wk & $\begin{array}{l}\text { Mitral valve } \\
\text { repair; homo- } \\
\text { graft mitral } \\
\text { valve } \\
\text { replacement }\end{array}$ & Ruptured chordae & Present & $\begin{array}{l}\text { Soft apical }+ \\
\text { left sternal } \\
\text { edge }\end{array}$ & NR & $\begin{array}{l}\text { Mitral para- } \\
\text { prosthetic } \\
\text { regurgitation }\end{array}$ \\
\hline 19 & $35 \mathrm{~F}$ & $8 \mathrm{mth}$ & $\begin{array}{l}\text { Closed mitral } \\
\text { valvotomy; } \\
\text { homograft } \\
\text { mitral valve } \\
\text { replacement }\end{array}$ & Calcification + & Present & $\begin{array}{l}\text { Left sternal } \\
\text { edge in- } \\
\text { creasing } \\
\text { inspiration }\end{array}$ & ++ & $\begin{array}{l}\text { Mitral para- } \\
\text { prosthetic } \\
\text { regurgitation }+ \\
\text { intravalvar } \\
\text { leak }\end{array}$ \\
\hline 20 & ${ }_{47} \mathrm{~F}$ & 2 , & $\mathrm{Nil}$ & Calcification + & Present & $\begin{array}{l}\text { Soft left } \\
\text { sternal edge }\end{array}$ & $\mathrm{Nil}$ & $\begin{array}{l}\text { Mitral para- } \\
\text { prosthetic } \\
\text { regurgitation }\end{array}$ \\
\hline 21 & $36 \mathrm{~F}$ & $29 "$ & $\mathrm{Nil}$ & $\mathrm{Nil}$ & Present & $\begin{array}{l}\text { Soft left } \\
\text { sternal edge } \\
\text { + apex }\end{array}$ & NR & $\begin{array}{l}\text { Mitral para- } \\
\text { prosthetic } \\
\text { regurgitation }\end{array}$ \\
\hline 22 & $49 M$ & $5 \mathrm{wk}$ & Nil & Floppy valve & - & None & NR & $\begin{array}{l}\text { Sinus rhythm, } \\
\text { aortic valve } \\
\text { replacement; } \\
\text { not catheter- } \\
\text { ized; mitral } \\
\text { paraprosthetic } \\
\text { regurgitation }\end{array}$ \\
\hline \multicolumn{9}{|c|}{ Group 4} \\
\hline 23 & $34 \mathrm{M}$ & $16 \mathrm{mth}$ & Nil & Calcification ++ & Present & None & $\mathrm{Nil}$ & $\begin{array}{l}\text { Aortic } \\
\text { regurgitation + } \\
\text { LV failure; } \\
\text { sinus rhythm; } \\
\text { ventricular } \\
\text { fibrillation at } \\
\text { catheterization }\end{array}$ \\
\hline 24 & $57 \mathrm{~F}$ & $4 \mathrm{yr}$ & $\mathrm{Nil}$ & Calcification + & Present & $\begin{array}{l}\text { Aortic systolic } \\
\text { murmur }\end{array}$ & NR & $\begin{array}{l}\text { Aortic } \\
\text { regurgitation }\end{array}$ \\
\hline
\end{tabular}

NR not recorded.

$+\quad=$ mild $/$ moderate.

$++=$ severe.

oblique position, and particular care was taken to ensure that the catheter did not interfere with the function of the prosthesis. In two cases, of whom one had a paraprosthetic leak, the left atrium was entered from the left ventricle. Mitral regurgitation was classified as mild, moderate, or severe, puffs of 'smoke-ring' incompetence being considered a normal finding (Rockoff et al., I966). Left ventricular function was considered to be impaired if ejection fraction was reduced, if the left ventricular end-diastolic pressure was greater than $12 \mathrm{mmHg}$ with respect to the mid-thorax, or if dyskinetic areas were present. Cardiac output was measured by the Fick method, oxygen uptake being measured by expired air analysis in 8 patients, and an assumed basal value being used in the remainder (Robertson and Reid, 1952).

\section{Echocardiography}

Echocardiograms were recorded with a simultaneous electrocardiogram using an Ekoline 20 ultrasonoscope. The position of the transducer was adjusted until a satisfactory record was obtained showing the interventricular septum and the endocardial surface of the posterior wall of the left ventricle. In all cases, the two echoes from the ball of the prosthesis, and those from the valve ring and the apex of the cage were identified first and the position of the septal echo was confirmed to be anterior to these (Fig. I). In several patients, further identification of the septal echo was obtained by recording a tricuspid valve echo immediately anterior to it. Septal movement was considered to be normal if the dominant movement during systole was in a posterior direction with respect to the transducer, and reversed if in an anterior direction. End-diastolic volume and stroke volumes were only calculated if septal movement was normal, since the measurement of these volumes in the presence of reversed septal movement has not yet been validated in this laboratory (Gibson, 1973). 


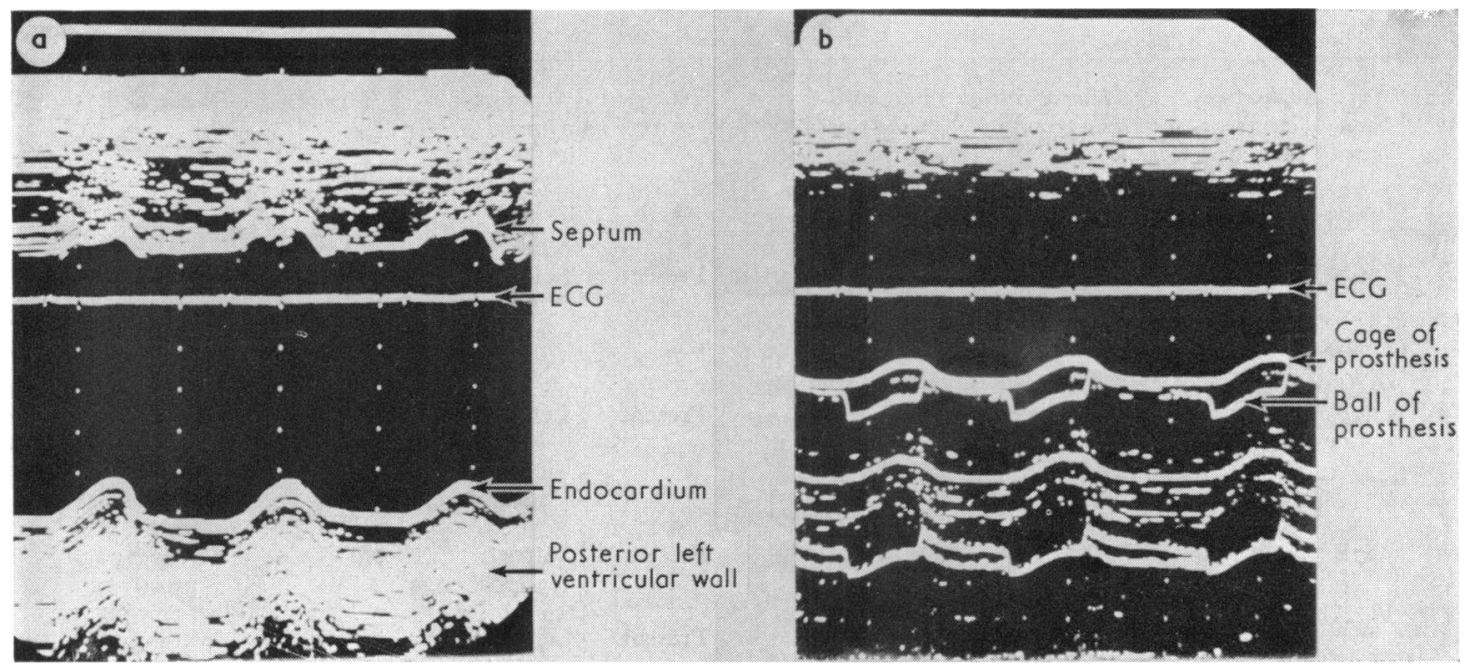

FIG. I a) An echocardiogram from a patient with Starr-Edwards mitral valve replacement demonstrating reversed septal movement. b) With the transducer in the same position and with the same gain settings, echoes from the prosthesis are demonstrated at a deeper plane.

\section{Phonocardiography}

Systolic time intervals were measured from high frequency phonocardiograms, which were recorded with a simultaneous electrocardiogram and indirect carotid pulse, using a Cambridge photographic recorder, operating at a paper speed of $100 \mathrm{~mm} / \mathrm{sec}$. At least ro successive beats were analysed for each patient, and the mean value taken. The following time intervals were measured:

(I) Left ventricular ejection time (LVET) taken as the interval between the onset of the rapid upstroke of the carotid pulse and the incisura.

(2) Pre-ejection period (PEP). This was taken as electromechanical systole $\left(\mathrm{QA}_{2}\right)$ less LVET.

(3) $\mathrm{QS}_{1}$, taken as the interval between the onset of the $\mathrm{q}$ wave and the high frequency closing click of the mitral prosthesis.

(4) $\mathrm{A}_{2} \mathrm{OC}$ interval, between the aortic closing sound and the mitral opening sound. LVET and PEP were corrected for heart rate according to the regression equations of Weissler and Garrard (1971), and differences between observed and predicted values expressed as $\triangle \mathrm{LVET}$ or $\triangle \mathrm{PEP}$.

\section{Haemolysis}

This was considered to be present if there was a raised reticulocyte count in the absence of recent blood loss, or evidence of red cell fragmentation on the blood film. It was classified as mild or severe depending on whether the haemoglobin level was greater or less than $12 \mathrm{~g} / \mathrm{I} 00$ $\mathrm{ml}$ provided that there was no other cause for anaemia.

\section{Results \\ Predisposing factors (Table I)}

Seven patients with severe regurgitation (Group 3) had previously had a mounted homograft valve before the current prosthesis, and I further patient had had a paraprosthetic leak repaired. No patient in groups I or 2 had previously had an open operation on the mitral valve. The incidence of calcification, ruptured chordae, or 'floppy cusps' at the previous operation was similar in all groups and none had had subacute bacterial endocarditis. Only 2 patients with severe paraprosthetic regurgitation were found to have none of these predisposing factors.

\section{Clinical presentation (Table $\mathrm{I}$ )}

There was no significant difference between the groups in the time between operation and onset of deterioration, or in the mode of deterioration. Most deteriorated gradually after initial improvement, but two (Group 3) deteriorated suddenly and one deteriorated in the postoperative period. All had reduced exercise tolerance or clinical evidence of heart failure. The venous pressure was raised in all but $I$, and evidence of right or left ventricular enlargement was present in a proportion of all groups. All but 3 had a systolic murmur whose origin was not clear before investigation. In retrospect, of the 3 patients who had no systolic murmur, I had a 
severe mitral paraprosthetic leak, I had an obstructed mitral prosthesis, and I had an obstructed tricuspid prosthesis. Only 2 of the patients eventually shown to have a severe paraprosthetic leak were felt to have clear-cut clinical evidence of mitral regurgitation, and, in general, the loudness of the systolic murmur bore an inverse relation to the severity of the leak. The electrocardiogram showed no characteristic features, and chest $x$-ray was also unhelpful. It was not possible to separate patients with and without paraprosthetic leak on the basis of changes in the cardiac silhouette or pulmonary vascular pattern.

\section{Haemodynamic changes}

One severely ill patient was not catheterized, and in 5 patients satisfactory wedge pressures were not obtained due to the presence of pulmonary hypertension. Three patients had major complications. One patient in Group 4 developed ventricular fibrillation when the catheter entered the left ventricle. Of 2 patients with an additional aortic StarrEdwards prosthesis in Group 3, in whom the left ventricle was entered by the retrograde approach, I had an episode of asystole during angiography and the second had a brief episode of profound hypotension after withdrawal of the catheter, requiring external cardiac massage. All 3 quickly recovered to their previous state. Mean values of haemodynamic variables are shown in Table 2. It was not possible to distinguish patients with severe paraprosthetic leak on the basis of pulmonary artery pressure, cardiac index, left ventricular end-diastolic pressure, or mean mitral diastolic gradient across the prosthesis. The ' $v$ ' wave on the pulmonary artery wedge trace was significantly higher in the patients with regurgitation, but there was considerable overlap between the 2 groups.

\section{Echocardiography (Table 3)}

All patients in Groups I and 2 showed reversed septal movement, with a dominant anterior deflection in systole. In Groups 3 and 4, septal movement was normal in all but 2, I of whom was found at operation to have only a small paraprosthetic leak, the main abnormality being a para-ball leak due to a torn cloth-covered valve (Case 19). The reason for persistence of reversed septal movement in the remaining patient (Case 20) was not clear. After successful surgery in 8 patients in groups 3 and 4, septal movement returned to the typical reversed pattern in all but I patient, who showed a clear-cut change from a normal pattern to one considered to be intermediate but not truly reversed (Fig. 2). In all patients in whom septal movement was normal, calculated stroke volume was considerably greater than that derived at cardiac catheterization, consistent with the presence of significant valvular regurgitation (Fig. 3).

\section{Systolic time intervals (Table 3 )}

Comparisons were restricted to Groups I and 3. There was no statistically significant difference between values of $\triangle L V E T, \triangle P E P$, or $Q S_{1}$ between these two groups. However, $\mathrm{A}_{2} \mathrm{OC}$ was significantly reduced in those with mitral regurgitation, with only slight overlap between the groups. One patient (Case 9) in Group I had a value below normal (80 msec), and I patient in Group 3 had a value within the normal range (Case 20); in this one septal movement was also reversed on the echocardiogram. There did not appear to be any relation between the severity of the regurgitation and the degree of shortening of the $\mathrm{A}_{2} \mathrm{OC}$ interval.

\section{Haemolysis (Table I)}

The presence of haemolysis was not assessed in 8 patients. Severe haemolysis was confined to 3

TABLE 2 Haemodynamic parameters

\begin{tabular}{|c|c|c|c|c|c|}
\hline & $P A$ systolic & $L V E D P$ & C. Index & $\begin{array}{l}\text { Mitral mean } \\
\text { diastolic gradient }\end{array}$ & $\begin{array}{l}\text { ' } V \text { ' wave } \\
L A \text { or } P A W\end{array}$ \\
\hline $\begin{array}{r}\text { Group I } \\
\text { P }\end{array}$ & $\begin{array}{l}56 \cdot 1 \pm I 5 \cdot 2 \\
(9) \\
\text { NS }\end{array}$ & $\begin{array}{l}16 \cdot 8 \pm 4 \cdot 8 \\
(9) \\
\text { NS }\end{array}$ & $\begin{array}{l}1 \cdot 7 \pm 0.7 \\
(9) \\
\text { NS }\end{array}$ & $\begin{array}{l}7 \cdot 6 \pm 7 \cdot 0 \\
\text { (9) } \\
\text { NS }\end{array}$ & $\begin{array}{l}9.0 \pm 4.1 \\
(8) \\
<0.01\end{array}$ \\
\hline Group 2 & $\begin{array}{l}47 \\
(2)\end{array}$ & $\begin{array}{l}\mathbf{I} \mathbf{I} \\
(\mathbf{2})\end{array}$ & $\begin{array}{l}2 \cdot 6 \\
(2)\end{array}$ & $\begin{array}{l}6 \\
\text { (I) }\end{array}$ & $\begin{array}{l}14 \\
\text { (I) }\end{array}$ \\
\hline Group 3 & $\begin{array}{l}70 \pm 17 \cdot 8 \\
\text { (9) }\end{array}$ & $\begin{array}{l}\text { I5.4 } 45 \cdot 0 \\
\text { (10) }\end{array}$ & $\begin{array}{l}I \cdot 8 \pm 0.6 \\
(9)\end{array}$ & $\begin{array}{l}9 \cdot 7 \pm 7 \cdot 1 \\
(7)\end{array}$ & $\begin{array}{l}17 \cdot 8 \pm 7 \cdot 0 \\
(7)\end{array}$ \\
\hline Group 4 & $\begin{array}{l}74 \\
(2)\end{array}$ & $\begin{array}{l}\text { I2 } \\
\text { (I) }\end{array}$ & $\begin{array}{l}2 \cdot 5 \\
(I)\end{array}$ & NR & $\begin{array}{l}20 \\
(I)\end{array}$ \\
\hline
\end{tabular}

The mean values \pm SD are shown with the number of observations in parentheses. Statistical comparison between Groups $I$ and 3 gives values for $P$ as shown. 
TABLE 3 Systolic time intervals and echocardiographic data

\begin{tabular}{|c|c|c|c|c|c|c|c|}
\hline & $\triangle L V E T$ & $\triangle P E P$ & PEP/LVET & $Q S I$ & $A_{2}-O C$ & $\begin{array}{l}\text { Septal mor } \\
\text { Reversed }\end{array}$ & $\begin{array}{l}\text { Noment } \\
\text { Normal }\end{array}$ \\
\hline Group I & $\begin{array}{l}66 \cdot 1 \pm 40 \cdot 5 \\
(7)\end{array}$ & $\begin{array}{l}62 \cdot 4 \pm 20 \cdot 8 \\
(7)\end{array}$ & $\begin{array}{l}0.58 \pm 0.16 \\
(7)\end{array}$ & $\begin{array}{l}8 r \cdot 6 \pm 9 \cdot 9 \\
(7)\end{array}$ & $\begin{array}{l}\operatorname{III} \cdot 2 \pm 24 \cdot 3 \\
(8)\end{array}$ & & \\
\hline (9) & NS & NS & NS & NS & $\mathrm{P}<0.01$ & 9 & 0 \\
\hline $\begin{array}{l}\text { Group } 2 \\
\text { (2) }\end{array}$ & & & & & & 2 & 0 \\
\hline $\begin{array}{l}\text { Group } 3 \\
\text { (II) }\end{array}$ & $\begin{array}{l}72 \cdot 9 \pm 34 \cdot 7 \\
(8)\end{array}$ & $\begin{array}{l}40 \cdot 4 \pm 28 \cdot 5 \\
(8)\end{array}$ & $\begin{array}{l}0.46 \pm 0.15 \\
(8)\end{array}$ & $\begin{array}{l}67 \cdot 6 \pm 17 \cdot 7 \\
(8)\end{array}$ & $\begin{array}{l}79 \cdot 1 \pm 18 \cdot 3 \\
(8)\end{array}$ & 2 & 9 \\
\hline Group 4 & & & & & & 0 & 2 \\
\hline
\end{tabular}

The mean values $\pm S D$ are shown with the number of observations in parentheses. Values for $P$ refer to comparison between Groups I and 3. Values for Groups 2 and 4 have been omitted as only one patient in each group had systolic time intervals measured.

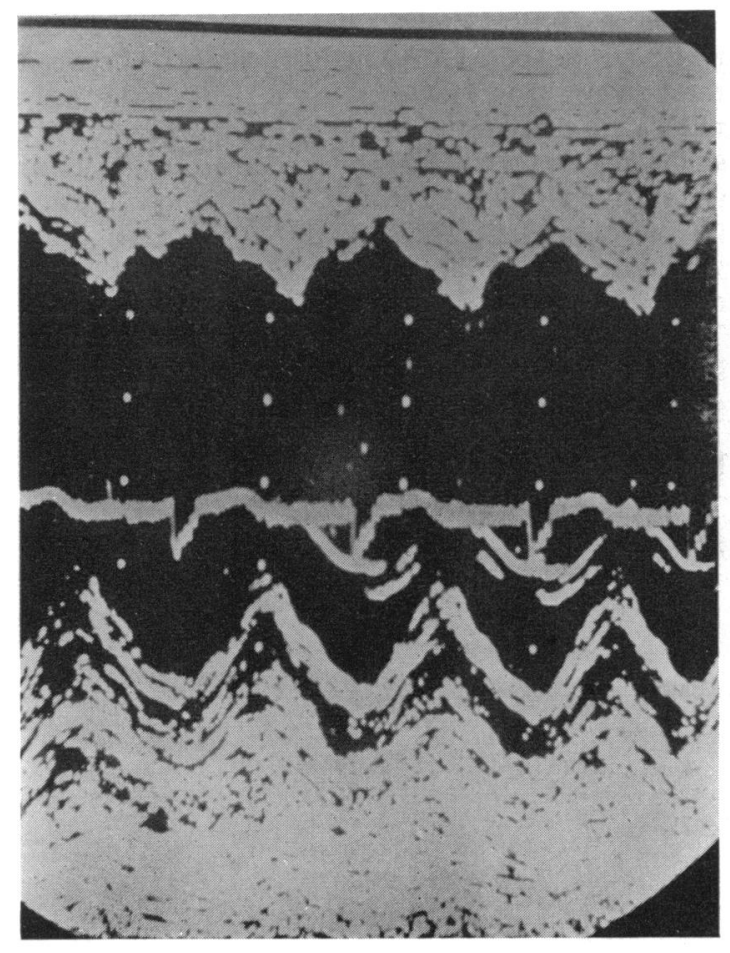

(a)

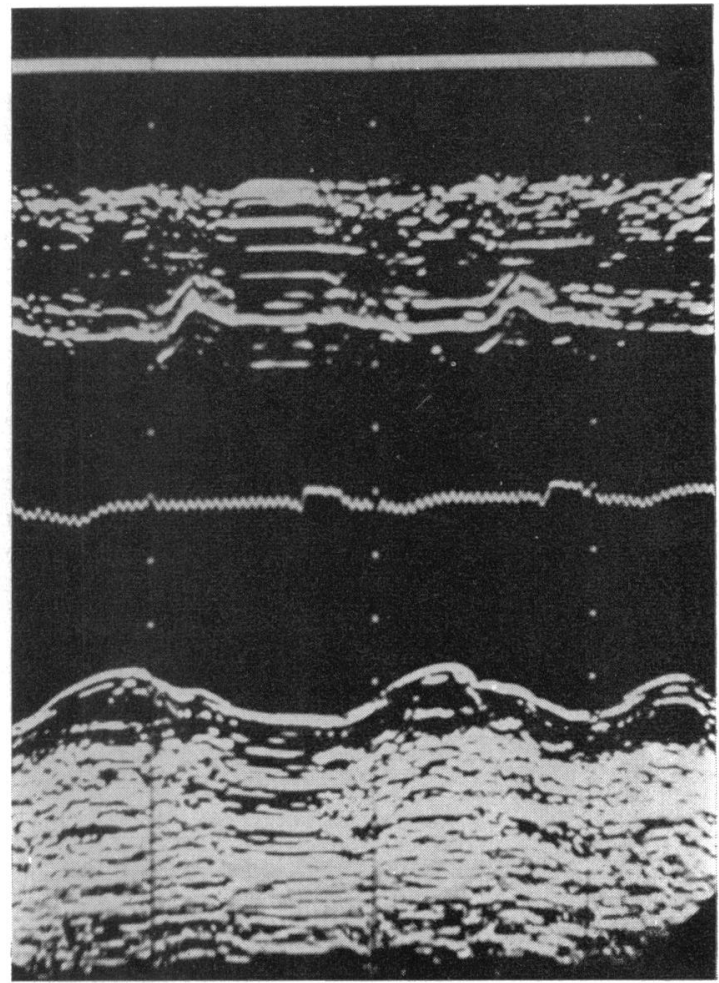

(b)

FIG. 2 a) An echocardiogram of Case 15 after the onset of mitral paraprosthetic regurgitation. Septal movement is normal, and stroke volume increased at $130 \mathrm{ml}$. b) After correction of regurgitation by further mitral valve replacement, septal movement has changed to an intermediate pattern, being neither normal nor typically reversed. 


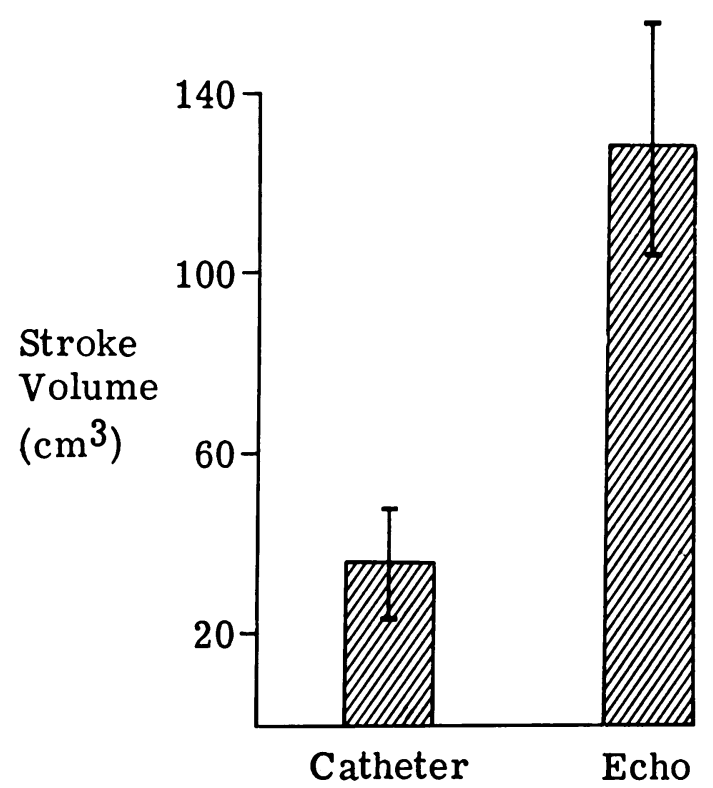

FIG. 3 Comparison of stroke volume measured by echocardiography and at cardiac catheterization in 9 patients (8 Group 3, I Group 4). The echocardiographic value reflects total left ventricular output, and catheter value net forward flow, the difference in values indicating the regurgitant fraction. Bars represent $S D$.

patients in Group 3 out of the 8 in whom it was assessed, and was not seen in the other groups. Slight haemolysis, seen as occasional red cell fragmentation on a blood film, was seen in I patient in Group I and 2 in Group 3.

\section{Discussion}

This study shows that reduced exercise tolerance or clinical evidence of heart failure after mitral valve replacement may be due to a number of causes, singly or in combination. These include mitral prosthesis obstruction, paraprosthetic leak, other valvular lesions including tricuspid stenosis and aortic regurgitation, as well as impaired left ventricular function. Since all but the last of these are potentially correctable by surgery, accurate diagnosis in such patients is of considerable importance in their management. We were therefore disappointed to find that the usual clinical criteria for the diagnosis of these conditions were almost uniformly unhelpful.

It has been well documented that important mitral paraprosthetic regurgitation may be silent, and this picture was shown by one case in the present series in whom no murmur was heard at any time (Morrow et al., 1964; Rockoff et al., 1966; Sanders, 1969). The reason for this is not clear. It has been attributed to the murmur being in an unusual site, such as posteriorly over the right scapula (Sawkar, 1969), and, though this emphasizes the need for careful physical examination, it was not present in our case. A more common problem, however, was that of a soft systolic murmur whose amplitude was reduced with medical treatment, and which was present in patients with or without mitral regurgitation. This appeared to be due to tricuspid regurgitation, though a soft systolic murmur may also result from a normally functioning mitral prosthesis caused by the presence of the cage in the left ventricular outflow tract. In the present series, as well as in previous ones (Willerson et al., 1972), a loud systolic murmur was more frequently due to a small leak which presumably causes more turbulence than a large one. It is clear, therefore, that the presence or absence of a systolic murmur is irrelevant in assessing the competence or otherwise of a mitral StarrEdwards valve.

Absence of the opening click of mitral prosthesis has been considered valuable evidence of mitral paraprosthetic leak (Aravanis, Toutouzas, and Stavrou, 1972), but failure to demonstrate this sign in all II patients in the present series makes us question its reliability. We were, however, able to confirm the finding of Willerson et al. (1972) that a decrease in the $\mathrm{A}_{2} \mathrm{OC}$ interval is a useful physical sign of mitral paraprosthetic leak. Only I patient (Case 20) with significant mitral regurgitation had a value in the normal range. She also had an echocardiographic anomaly showing reversed septal movement which we were unable to explain. Reduction in $\mathrm{A}_{2} \mathrm{OC}$ interval has also been reported with obstruction of a mitral prosthesis by Wise et al. (1971) who suggested that the increased mitral gradient caused a more rapid excursion of the ball. One patient in the present series with mitral obstruction had a $25 \mathrm{~mm}$ diastolic gradient across the prosthesis and a normal $\mathrm{A}_{2} \mathrm{OC}$ interval. However, there was no difference in mitral gradient between those patients with mitral paraprosthetic regurgitation and those with normally functioning prostheses in spite of the differences in $\mathrm{A}_{2} \mathrm{OC}$ interval. We conclude, therefore, that a reduction in $\mathrm{A}_{2} \mathrm{OC}$ interval is a valuable sign of mitral paraprosthetic leak but not necessarily of obstruction. Unlike Willerson et al., we found $\triangle$ LVET not to be significantly different between patients with and without mitral regurgitation. This may reflect our comparison with patients with heart failure rather than asymptomatic controls as used by them. The presence of significant haemolysis also failed to provide evidence for paraprosthetic regurgitation, being present in 
only 3 patients out of 8 in whom it was sought. This finding is in line with previous reports by Kastor et al. (1968) and Sanders (1969).

In view of these uncertainties in clinical assessment, cardiac catheterization was performed in all but I patient. Though abnormalities in intracardiac pressures give information about the physiological consequences of an abnormality, they may not allow the nature of the underlying abnormality to be diagnosed. This was emphasized in the patient in Group 4 who developed ventricular fibrillation when the catheter entered the left ventricle so that angiography was not performed, and an incorrect diagnosis of a paraprosthetic leak was made on the basis of a tall ' $v$ ' wave on the pulmonary artery wedge trace. We consider, therefore, that left ventriculography is the definitive investigation for the diagnosis of mitral paraprosthetic leak, though it should be recognized that false positive results may occur due to interference with valve function by the presence of the catheter across the cage (Barold, Javier, and Linhart, 1968). In addition, it carries a significant morbidity, particularly in severely ill patients, and especially in those in whom an aortic prosthesis is crossed retrogradely. Additional non-invasive tests would therefore be of value in screening patients for more definitive investigation.

We found that observation of septal movement was of value in the diagnosis of mitral paraprosthetic regurgitation. Septal movement was reversed in all patients in Groups I and 2, while it showed a normal pattern of movement in 9 out of the II patients in Group 3 in whom there was a significant paraprosthetic leak. Normal septal movement was not specific for mitral paraprosthetic regurgitation since it also occurred in the presence of aortic regurgitation even if this is clinically undetected (Group IV). The mechanism is not certain. It appears to be unrelated to right ventricular overload or tricuspid regurgitation whose incidence was similar in Groups I and 3, and which, in other conditions, is usually associated with reversed, rather than normal, septal movement. It is not due to the cage of the prosthesis, since it may also occur with a Björk-Shiley prosthesis (unpublished observation) which has no cage. It is possible that it reflects abnormalities of diastolic filling, since a normally functioning mitral Starr-Edwards valve is obstructive (Kezdi, Head, and Buck, 1964). In early diastole, therefore, filling of the right ventricle might be expected to occur more rapidly than that of the left, causing posterior movement of the septum. This would explain its reversion to normal with conditions causing significant ventricular filling by some route other than through the prosthesis itself either by a paraprosthetic dehiscence, or from the aortic root. Normal septal movement would not occur, therefore, with a small paraprosthetic leak (Group 2), or a leak dominantly through the ring rather than around it (Case 19).

A second echocardiographic feature of mitral paraprosthetic regurgitation was the presence of a very large stroke volume measured by echocardiography in comparison with that derived from cardiac catheterization. This was also present with aortic regurgitation. Though estimation of stroke volume may be affected by abnormalities of ventricular shape or by the presence of dyskinesia (Gibson, 1973), in the present series it was found that the disparity between stroke volume measured echocardiographically and at cardiac catheterization bore a relation to the severity of mitral paraprosthetic regurgitation or aortic regurgitation as assessed by angiography or at reoperation.

In conclusion, we feel that dysfunction of the mitral prosthesis should be considered in any patient who fails to show sustained improvement after mitral valve replacement. Unfortunately, physical examination, chest $x$-ray, electrocardiogram, and assessment of haemolysis are all unhelpful in establishing the diagnosis. A reduced $\mathrm{A}_{2} \mathrm{OC}$ interval, and normal septal movement with an inappropriately large stroke volume on echocardiography, are all extremely suggestive of a mitral paraprosthetic leak, and indicate that definitive diagnosis should be made by left ventriculography. This may carry a significant risk, however, and on the basis of these results, we are now prepared to recommend operation in a severely ill patient on the basis of echocardiographic findings alone.

We wish to thank our colleagues for permission to report on their patients.

\section{References}

Aravanis, C., Toutouzas, P., and Stavrou, S. (1972). Disappearance of opening sound of Starr-Edwards mitral valve due to valvular detachment. British Heart fournal, 34, 1314.

Barclay, R. S., Reid, J. M., Stevenson, J. G., Welsh, T. M., and McSwan, N. (1972). Long term follow-up of mitral valve replacement with Starr-Edwards prosthesis. British Heart fournal, 34, 129.

Barold, S. S., Javier, R. P., and Linhart, J. W. (1968). Factitious mitral insufficiency. A pitfall in the hemodynamic assessment of prosthetic mitral valves by retrograde catheterization of the left side of the heart. New England fournal of Medicine, 279, $8 \mathrm{ro}$.

Gibson, D. G. (1973). Estimation of left ventricular size by echocardiography. British Heart fournal, 35, 128.

Kastor, J. A., Akbarian, M., Buckley, M. J., Dinsmore, R. E., Sanders, C. A., Scannell, J. G., and Austen, W. G. (1968). Paravalvular leaks and hemolytic anemia following insertion of Starr-Edwards aortic and mitral valves. Fournal of Thoracic and Cardiovascular Surgery, 56, 279. 
Kezdi, P., Head, L. R., and Buck, B. A. (1964). Mitral ballvalve prosthesis. Dynamic and clinical evaluation. Circulation, 30, 55 .

Morrow, A. G., Harrison, D. C., Ross, J., Jr., Braunwald, N. S., and Clark, W. D. (1964). The surgical management of mitral valve disease : a symposium on diagnostic methods, operative techniques, and results. Annals of Internal Medicine, 60, 1073.

Morrow, A. G., Oldham, H. N., Elkins, R. C., and Braunwald, E. (1967). Prosthetic replacement of the mitral valve. Preoperative and postoperative clinical and hemodynamic assessments in 100 patients. Circulation, 35, 962.

Najafi, H., Dye, W. S., Javid, H., Hunter, J. A., Ostermiller, W. E., and Julian, O. C. (1969). Mitral valve replacement. Review of seven years' experience. American fournal of Cardiology, 24, 386.

Peterson, C. R., Herr, R., Crisera, R. V., Starr, A., Bristow, J. D., and Griswold, H. E. (1967). The failure of hemodynamic improvement after valve replacement surgery. Etiology, diagnosis, and treatment. Annals of Internal Medicine, 66, $\mathrm{I}$.

Robertson, J. D., and Reid, D. D. (1952). Standards for the basal metabolism of normal people in Britain. Lancet, $\mathbf{I}$, 940.
Rockoff, S. D., Ross, J., Jr., Oldham, N. N., Jr., Mason, D. T., Morrow, A. G., and Braunwald, E. (I966). Ventriculoatrial regurgitation following prosthetic replacement of the mitral valve. Angiocardiographic and hemodynamic findings. American fournal of Cardiology, 17, 817.

Sanders, C. A. (1969). Editorial: prosthetic problems. New England fournal of Medicine, 281, 501.

Sawkar, L. (1969). Unusual location of the mitral-prosthesis murmur. New England fournal of Medicine, 281, 1075.

Starr, A. (I97I). Mitral valve replacement with ball valve prosthesis. British Heart fournal, 33, Suppl., 47.

Weissler, A. M., and Garrard, C. L. (1971). Systolic time intervals in cardiac disease. Modern Concepts of Cardiovascular Disease, 40, I.

Willerson, J. T., Kastor, J. A., Dinsmore, R. E., Mundth, E., Buckley, M. J., Austen, W. G., and Sanders, C. A. (1972). Non-invasive assessment of prosthetic mitral paravalvular and intravalvular regurgitation. British Heart Fournal, 34, 561.

Wise, J. R., Webb-Peploe, M., and Oakley, C. M. (1971). Detection of prosthetic mitral valve obstruction by phonocardiography. American fournal of Cardiology, 28, 107.

Requests for reprints to Dr. D. G. Gibson, Cardiac Department, Brompton Hospital, London SW $36 \mathrm{HP}$. 